\title{
Anti-Intellectualism, Populism, and Motivated Resistance to Expert Consensus $^{1}$
}

\author{
Eric Merkley \\ Munk School of Global Affairs \& Public Policy \\ University of Toronto \\ eric.merkley@utoronto.ca
}

Forthcoming in Public Opinion Quarterly

\begin{abstract}
Scholars have maintained that public attitudes often diverge from expert consensus due to ideologydriven motivated reasoning. However, this is not a sufficient explanation on less salient and politically-charged questions. I argue that more attention needs to be given to anti-intellectualism the generalized mistrust of intellectuals and experts. I make three main contributions using the General Social Survey and a survey of 3,600 Americans on Amazon Mechanical Turk. First, I provide evidence of a strong association between anti-intellectualism and opposition to scientific positions on climate change, nuclear power, GMOs, and water fluoridation, particularly for respondents with higher levels of political interest. Second, I conduct a survey experiment to show that anti-intellectualism moderates the acceptance expert consensus cues such that respondents with high levels of anti-intellectualism actually increase their opposition to these positions in response. Third, I connect anti-intellectualism to populism - a worldview that sees political conflict as primarily between ordinary citizens and a privileged societal elite. I show that exposure to randomly assigned populist rhetoric - even that which does not pertain to experts directly - primes antiintellectual predispositions among respondents in the processing of expert consensus cues. These findings suggest that rising anti-elite rhetoric may make anti-intellectual sentiment more salient in information processing.

${ }^{1}$ Grateful for the helpful feedback from my committee: Paul Quirk, Richard Johnston, and Fred Cutler, and from my external examiner John Bullock. And, thanks to Dominik Stecula, April Clark, Shane Singh, and participants at the Comparative-Canadian Workshop at UBC for useful comments.
\end{abstract}


Citizens are often in disagreement with scientific opinion on a wide range of issues that have important implications for policy making. The bulk of scholarly attention has been dedicated to climate change. At some level this is understandable. Climate change is one of the most pressing issues of our time, and one where we have struggled to find and implement long-term policy solutions. However, a focus on climate change potentially distorts our understanding of citizens' acceptance of expert advice on other issues. A large majority of citizens in the United States agree with the climate change consensus, but opinion is heavily structured by ideology and partisanship. Thus, explanations about the failure of citizens to accept expert advice tend to center on ideologydriven motivated reasoning (i.e. Kahan et al. 2011; Lewandowsky and Oberauer 2016) anchored in psychological theories of information processing (Ditto and Lopez 1992; Kunda 1990). But, this is not obviously the case with other less politicized issues, like the safety of genetically modified organisms (GMOs), nuclear power, or water fluoridation, among others, where there is substantial disagreement between experts and the public. ${ }^{2}$

I advance the argument here that one important predisposition that govern citizens' acceptance of expert knowledge is anti-intellectualism - a generalized mistrust of experts and intellectuals. Little work has explored the nature of this predisposition and how it may shape attitudes towards areas of expert consensus. This paper contributes to this nascent literature in three ways. First, I establish anti-intellectualism as a strong predictor of disagreement with positions of expert consensus on both highly salient and polarizing issues, like climate change, and other issues that score lower on these characteristics, such as water fluoridation. Second, I demonstrate that antiintellectualism moderates the persuasiveness of messages of expert consensus on these same issues using a survey experiment. Third, I connect anti-intellectualism to the broader predisposition of populism. I show with my experimental design that anti-elite rhetoric - even rhetoric that does not directly pertain to experts and intellectuals - can prime anti-intellectualism as a predisposition.

\footnotetext{
${ }^{2}$ For example, a Pew Survey (2015) found that 88 percent of members of the American Association for the Advancement of Science think GMOs are safe to eat, versus only 37 percent of Americans. Pew found an average gap of 24 percentage points between AAAS members and the public across 13 different items.
} 


\section{Anti-intellectualism and the Rejection of Expert Consensus}

Scholars, starting with the foundational work of Hoftstader (1962), have shown that antiintellectualism has a long history in American politics. He argues this worldview is anchored in a belief that "intellectuals....are pretentious, conceited... and snobbish; and very likely immoral, dangerous, and subversive" (Hoftstader 1962, 19). Experts are seen as dangerous because they occupy the halls of power and profess to know how citizens should better run their lives. The rising importance of experts with the growth of government after the Second World War may have helped spark a rise in anti-intellectualism (Hofstadter 1962).

Not all scholars agree on how to conceptualize anti-intellectualism. Rigney (1991) identifies three distinct components to anti-intellectualism: 1) Anti-rationalism, or the dismissal of critical thinking as a desirable trait; 2) Unreflexive instrumentalism, or the devaluing of long term payoffs for short term material gain; and 3) anti-elitism, or the disparagement of intellectuals and experts. Some have viewed anti-intellectualism as a rhetorical style that emphasizes plain-spokenness (Lim 2010; Shogun 2007), while others see it as an important component of populist rhetoric (Brewer 2016; Harris 2010; Kazin 1995).

For my purposes here, anti-intellectualism is defined as a generalized suspicion and mistrust of intellectuals and experts of whatever kind. Such contempt can have a number of sources. Some citizens might perceive expert authority as fundamentally at odds with religious authority that they may privilege. Or, they might not see the value of education and critical thought, particularly if they see it as coming at the expense of practical knowledge and common sense (Rigney 1991). Or, they may be skeptical of acquired knowledge because they see it as a tool of an exploitative societal elite (Brewer 2016) - a point which will be returned to below. Whatever the source, the result is a generalized mistrust of intellectuals and expert authority.

Anti-intellectualism has important implications for citizens' acceptance of expert consensus where it exists. Perceptions of speaker knowledge are important for messages to be persuasive to the lay citizen, but they are not sufficient. Citizens need to trust speakers as well, which is largely dependent on the perception of common interests (Lupia and McCubbins 1998). By definition, those that hold anti-intellectual predispositions lack this trust in expert sources. Thus, we should expect them to exhibit lower levels of agreement with important positions of scientific consensus. Motta (2018) found this to be the case for climate change and the safety of nuclear power, but it should also apply to issues of lesser salience. 
Hypothesis 1 (H1): Anti-intellectualism is correlated with opposition to positions of expert consensus holding other factors constant.

Science communication scholars have turned to consensus cues - clear statements that signal there is a scientific or expert consensus on a question - as a mechanism to persuade citizens on issues like climate change (van der Linden et al. 2015, 2019). These works are one part of a broader literature showing that corrections or "fact-checks" are often effective at rectifying misperceptions (Berinsky 2017; Nyhan and Reifler 2010, 2015; Wood and Porter 2019). The willingness to accept and be persuaded by consensus cues, however, should be highly conditional on one's level of antiintellectual sentiment.

Hypothesis 2 (H2): The effect of consensus cues on support for positions of expert consensus will be weaker among those with higher levels of anti-intellectual sentiment.

\section{Populist Rhetoric and the Priming of Anti-intellectualism}

Anti-intellectual sentiment should shape how willing one is to be persuaded by expert consensus where it exists. There may also be factors in the real world that intensify this reaction. One possibility is populist rhetoric.

The study of populism has been extensive, but there has been tremendous disagreement on how to define it. Kazin (1995) argues that populism is a worldview that pits average citizens, imagined as a collective, against elites in political and economic conflict. Other scholars have treated populism as a rhetorical strategy that links populist movements globally (Roodujn 2014). Following these scholars, and others (Mudde 2004; Taggart 2000) I treat populism as both a worldview and a rhetorical strategy employed by politicians that emphasizes conflict between the people, imagined as a collective, and political elites or the establishment.

In short, populism is minimally defined by its anti-elitism - a hostility towards elites, of whatever kind and for whatever reason. The roots of this anti-elitism can vary. On the political left, hostility towards elites is anchored in concerns about the wealth and privilege of economic elites and their effects on marginalized communities. On the political right, this suspicion may be fueled by a concern about excessive government power over individuals. In either case, ire is directed towards societal elites for reasons that are not linked to the level of intellect or education of those elites. Recently, populist sentiment has seen a resurgence in the aftermath of the Financial Crisis, 
manifesting in the rise of the Tea Party and Donald Trump on the right (Motta 2018; Skocpol and Williamson 2013) and the growing clout of liberal populists in the Democratic Party (Oliver and Rahn 2016).

There is likely to be a strong connection between populism and anti-intellectualism. Suspicion of experts can be rooted in a perception that their knowledge will be used to control ordinary citizens, which shades into populist discourse. As Brewer notes "American populism tends to be highly resentful of being told by experts 'we know best"' $(2017,253)$. Some populists may see experts as part of the ruling elite because of their status and importance in policy debates.

In short, populist sentiment is likely a source of anti-intellectualism, though it is not likely to be the only one. A mistrust in intellectuals and experts can, for example, be rooted in religious fundamentalism, where intellectuals and experts are seen as a threat to religious authority. It can be fueled by ideology and partisanship, particularly in periods where intellectual and expert opinion crystalize on one side of the political divide. We can also imagine that anti-intellectualism has some connection to other personality characteristics, like a propensity for intuitionist over rationalist thinking (Oliver and Wood 2018). The important point is that these other possible sources of antiintellectualism are conceptually distinct of populism. Populist sentiment is not necessary for antiintellectualism.

Similarly, anti-intellectualism is not an inevitable by-product of populism. The degree to which intellectuals and experts are identified as part of the ruling elite likely varies at the individual-level and over time (Rigney 1991). For example, populist progressives in the early $20^{\text {th }}$ century saw expertise and professionalism as a solution to the machine politics they abhorred. Marxist leaders often makes considerable use of anti-elite rhetoric, but their movement has historically often been led by intellectuals and fueled by important philosophical texts. Populism and anti-intellectualism have a complex relationship. They are connected to one another, but the latter should not be seen as a component of the former.

The conceptual connection between populism and anti-intellectualism suggests that anti-elite rhetoric may have important implications for the public's support for positions with expert consensus. Rhetoric has the power to shape political attitudes (Chaiken 1980; Petty and Cacioppo 1986). Most importantly for my purposes here, rhetoric can prime citizens to evaluate candidates and policy based on certain issues or underlying predispositions (Iyengar and Kinder 1987). For example, presidential rhetoric related to specific issues can shape the criteria by which he or she is evaluated by the public (Druckman and Holmes 2004), and racial rhetoric - at least that which is implicit - 
activates racial attitudes when citizens evaluate candidates and policies like social welfare (Mendelberg 2001).

Rhetoric can also link people's worldviews to science-related questions. Scholars have found that moral rhetoric can activate citizens' moral intuitions in shaping attitudes toward environmental protection and science-related questions (Barker 2005; Clifford et al. 2015; Feinberg and Willer 2013; Haider-Markel and Joslyn 2001; Kidwell et al. 2013; Shen and Edwards 2005; Winterich et al. 2012). For example, rhetoric on stem cell research that tapped into the care foundation - according to Haidt's moral foundations theory (2001) - was found to be persuasive among those that score high on that foundation (Clifford et al. 2015).

An association between populism and anti-intellectualism would suggest that for many people experts are seen as elites. If this is true, we might expect anti-elite rhetoric to prime antiintellectualism as a predisposition to shape people's propensity to accept expert consensus cues. More specifically, anti-elite rhetoric should further diminish the persuasive effect of consensus cues among those with higher levels of anti-intellectualism - even when that rhetoric does not directly pertain to experts and related issues.

Hypothesis 3 (H3): The effect of consensus cues on support for positions of expert consensus will be weaker among those with higher levels of reported antiintellectualism, particularly when exposed to anti-elite rhetoric.

\section{Data and Methods for Observational Analysis}

I use the General Social Survey (GSS) and a non-probability sample of 3,614 voting age American citizens collected from July 15-17 through Amazon Mechanical Turk (MTurk). The latter sample cannot make claims to representativeness, but some of its broad characteristics are similar to the public as a whole. Table S1 of the online supplementary material provides a comparison of the 2016 GSS and the MTurk sample used in the paper. MTurk respondents are reasonably representative of the American population in terms of gender, race, partisanship, and ideology, but it is substantially younger, more educated, less religious, and more affluent. I use the GSS to check whether the observational findings in my MTurk sample hold for a more representative sample. 


\section{Measuring Anti-intellectualism}

Research on theorizing and measuring anti-intellectualism is scarce. One recent exception by Motta (2018) used a question in the GSS that asked respondents their degree of confidence in the scientific community (a great deal/only some/hardly any). I use this question for my GSS analyses as well, rescaled from 0 to 1 where 1 is having hardly any confidence in the scientific community. The full descriptions of the variables in the following analyses can be found in Table S2 of the online supplementary material. This is obviously insufficient on its own. Confidence is not the same concept as trust, while the scientific community only represents one set of actors in a broader constellation of experts and intellectuals in society.

Oliver and Rahn (2016) measured anti-intellectualism with a three-question battery that they found correlates strongly with conservative ideology and religious fundamentalism. But, their questions tap strongly into populist themes, while emphasizing attitudes toward science rather than intellectuals and experts more broadly. ${ }^{3}$ Anti-intellectualism is certainly related to these issues, but, as discussed in the previous section, it is likely a more complex concept that is not fully captured by these questions.

Absent theoretical work that teases out the dimensions of anti-intellectualism for measurement purposes, I lean on the conceptualization I advance here. Whatever the particular source of anti-intellectualism - religious fundamentalism, ideology, populism, or intuitionism citizens with such sentiment will have a generalized mistrust of experts. So, I gave respondents a randomized battery where they rated their trust in a number of different groups in society with the following lead (distrust a lot to trust a lot, 7-point):

Below is a list of groups in society. Please tell us the degree to which you trust or distrust members of these groups.

\footnotetext{
${ }^{3}$ 1) I'd rather put my trust in the wisdom of ordinary people than the opinion of experts and intellectuals; 2) When it comes to really important questions, scientific facts don't help that much; 3) Ordinary people can really use the help of experts to understand complicated things like science and health (reverse coded).
} 
Among these groups were experts, scientists, economists, university professors, doctors and medical professionals, legal professionals, and financial experts. The intent was to provide respondents with a number of different professions where members engage in intellectual or academic pursuits to acquire established forms of expertise with which respondents would likely be familiar. I also wanted a breadth of professions that are not exclusively related to the natural sciences.

The distributions of these variables are displayed below in the left panel of Figure 1 as box plots. Americans are generally trusting of experts across the board, but scientists and doctors have an edge over most groups with a median of 5 on the 0 to 6 scale, while legal professionals are trusted the least with a median of 4. Legal professionals aside, only one quarter of respondents or less are distrusting - at any level - of any given expert community.
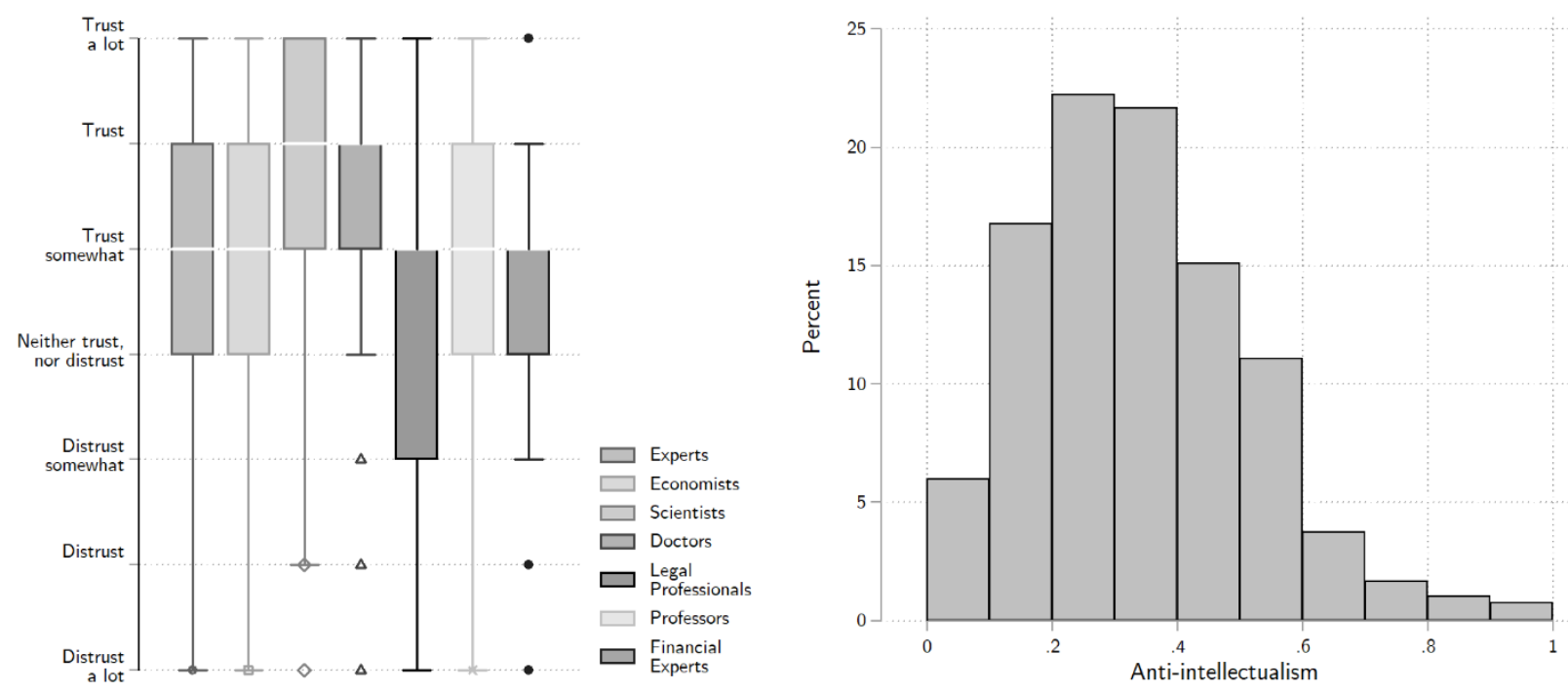

Figure 1. Distributions of trust in expert communities, box plots (left); Distribution of antiintellectualism, histogram (right)

I construct an index of all of these groups, rescaled from 0 to 1 where 1 is the most antiintellectual as indicated by a consistent and complete mistrust of various expert communities. ${ }^{4}$ The

\footnotetext{
${ }^{4}$ Principal components analysis reveals that these items load together strongly on one dimension. The Cronbach's Alpha on such an index is 0.86, suggesting high reliability, and item drop scores show us that the reliability of the index cannot be improved by removing any items. This information is provided in Table S3 of the online supplementary material.
} 
distribution of this measure is displayed in the right panel of Figure 1. Anti-intellectualism as measured here is not all that common among respondents. The average score is approximately 0.34 on the 0 to 1 index. Further, approximately two thirds of Americans find themselves between 0.17 and 0.51 , indicating a reasonably narrow distribution. Only about $20 \%$ of respondents find themselves at the mid-point of the scale or higher.

\section{Model}

The GSS questions has a trio of questions related to expert consensus on climate change, nuclear power, and GMOs. ${ }^{5}$ 72\% of Americans believed coal and gas definitely or probably contributed to the greenhouse effect. $83 \%$ of Americans viewed nuclear power as somewhat to extremely dangerous for the environment, while $72 \%$ thought the same for GMOs.

These three issues represent important areas of expert consensus, but there are a few critical limitations with these questions. First, they have only been asked sporadically and fairly long ago (e.g. 1993, 1994, and 2000 for climate change). Second, the questions related to nuclear power and GMOs do not address perceptions of the safety of these technologies for humans, which is the central area of scientific consensus on these issues. Finally, while opposition to GMOs is historically less ideologically charged than climate change or nuclear power, it would be useful to have a question related to an issue that completely lacks salience.

As a result, I had my MTurk respondents report their level of agreement with four positions of expert consensus related to climate change, nuclear power, GMOs, and water fluoridation, the first three of which feature different question wordings from the GSS. ${ }^{6} 80 \%$ of MTurk respondents

${ }^{5}$ 1) Using coal or gas contributes to the greenhouse effect (definitely true to definitely not true, 4point; asked in 1993, 1994, and 2000); 2) How dangerous is nuclear power for the environment? (extremely dangerous to not dangerous at all, 5-point; asked in 1993, 1994, and 2010); 3) How dangerous is modifying genes in crops for the environment? (extremely dangerous to not dangerous at all, 5-point; asked in 2000 and 2010)

${ }^{6}$ 1) Earth's climate is warming and this is due to the human production of greenhouse gases like carbon dioxide; 2) Nuclear power is a safe and environmentally-friendly form of energy production compared to conventional sources of energy like fossil fuels; 3) Genetically modified foods are safe, and pose no greater risk to human health than non-GM foods; 4) Water fluoridation improves oral and dental health with no safety risk (strongly agree to strongly disagree, 7-point). 
agreed at some level with the expert position on climate change, compared to $48 \%$ on nuclear power, $46 \%$ on GMO safety, and $53 \%$ on water fluoridation. I rescale these measures from 0 to 1 where 1 indicates full support for the expert position. I estimate the following model using OLS regression to examine the association between anti-intellectualism and support for each of our expert positions where $\mathrm{X}$ represents a vector of additional control variables. ${ }^{7}$

support for expert position $=\alpha+\beta_{1}$ anti-intellectualism $+\mathrm{X}+\varepsilon$

I control for ideology, which is measured is measured as a 7-point scale (extremely liberal to extremely conservative), and partisanship, which is measured in a similar fashion (strong Democrat to strong Republican). Both of these variables are rescaled from 0 to 1 . Controls for education and political interest are also worth noting. They are used here to soak up information effects. It is possible that anti-intellectuals are simply not as informed about positions of expert consensus, and it is this lack of information that is doing the heavy lifting as opposed to the motivated rejection of expert messages. $\beta_{1}$ should be negative and significant to support $\mathrm{H} 1{ }^{8}$

\section{Observational Results}

The results for the observational analyses testing H1 are displayed in Figure 2. The top panel plots the coefficients for anti-intellectualism (operationalized as confidence in the scientific community) and ideology in the GSS. The full estimation results can be found in Tables A1 and A2 of the Appendix. The results display a consistent link between anti-intellectualism and opposition to positions of expert consensus.

In the GSS sample, moving from having a great deal of confidence in the scientific community to having no confidence is associated with a 0.05 drop in support for the scientific consensus on the greenhouse effect ( $\mathrm{p} \sim 0.03$, two-tailed here and throughout). It is also associated with a $0.05(\mathrm{p} \sim 0.02)$ and 0.08 reduction $(\mathrm{p} \sim 0.008)$ in the perceived safety of nuclear power and

\footnotetext{
${ }^{7}$ The estimation based on the MTurk data was only done on respondents in the control condition $(\mathrm{N}=619)$ to ensure these estimates are not contaminated with experimental effects.

${ }^{8}$ GSS analyses are weighted with WTSSALL as recommended by the GSS user guide. MTurk results are unweighted.
} 
GMOs, respectively, on 0-1 scales. Ideology, in contrast, has inconsistent effects. Conservative ideology is negatively associated with support for the scientific consensus on the greenhouse effect ( $p \sim 0.03$ ), while it is positively associated with the expert position on nuclear power $(\mathrm{p} \sim 0.07)$. Antiintellectualism is a more consistent predictor of resistance to expert consensus than ideology in the GSS sample.
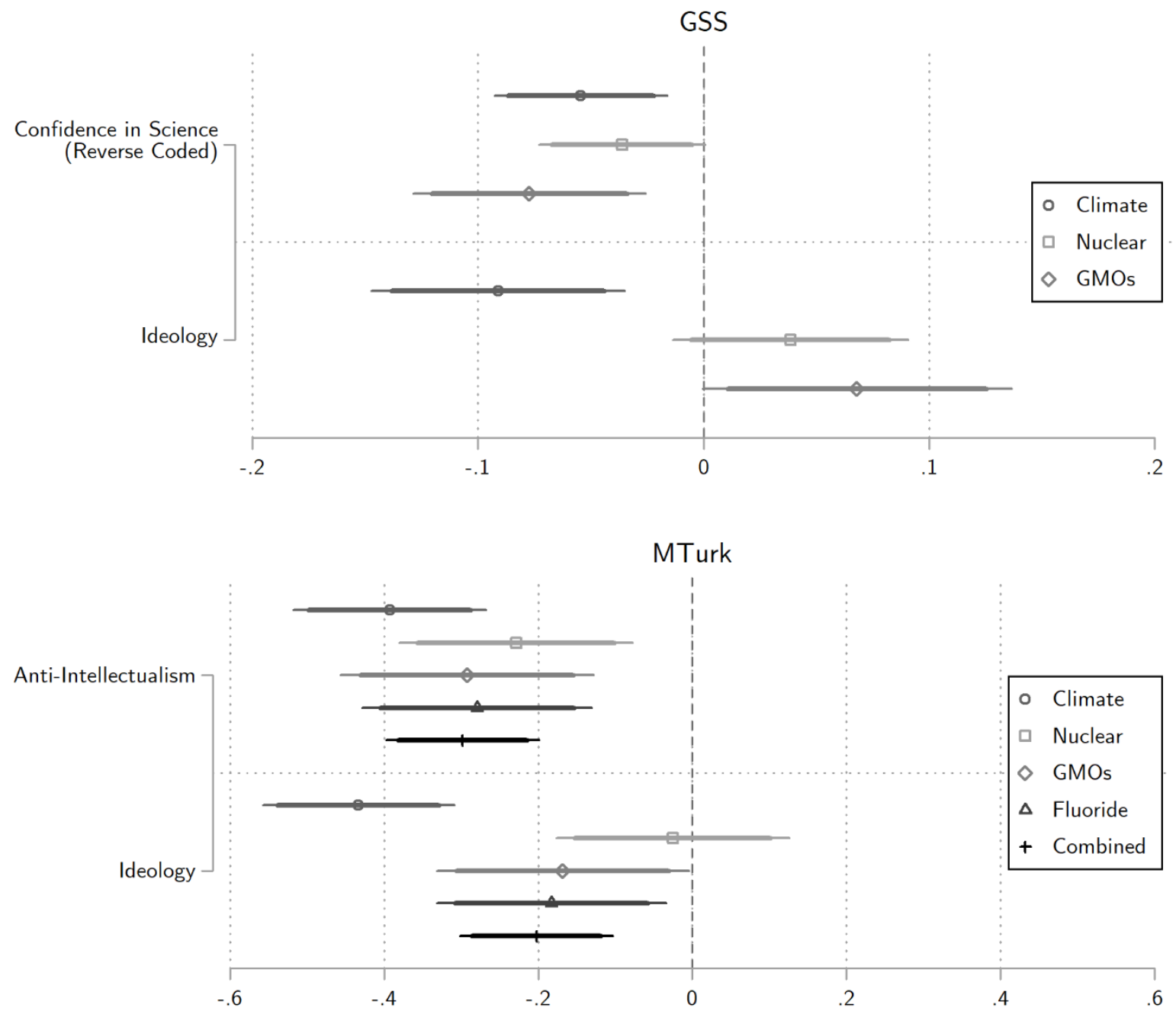

Figure 2. Determinants of support for expert consensus in GSS (top) and MTurk sample (bottom). Note: controls for gender, employment status, race, age, income, education, church attendance, partisanship, generalized trust, and political interest (MTurk only). 95 and 90\% confidence intervals.

Even stronger findings are found in the MTurk sample. The coefficients are displayed in the bottom panel of Figure 2. The consistent strength of the association between anti-intellectualism and opposition to scientific consensus is striking. Moving across the anti-intellectualism index is 
associated with a reduction of 0.39 points in support for the scientific consensus for climate change ( $p \sim 0.003), 0.23$ points for nuclear power ( $p<0.001), 0.29$ points for GMOs $(p<0.001)$, and 0.28 points for water fluoridation on $0-1$ scales $(\mathrm{p}<0.001)$. These are sizable effects. When averaging across all issues, movement across the range of the anti-intellectualism index is associated with a reduction in support for positions of expert consensus of 0.30 points $(p<0.001) .{ }^{910}$

Conservative ideology is associated with opposition to the climate consensus $(p<0.001)$, GMOs ( $p \sim 0.04)$, and fluoride ( $p \sim 0.02)$. Averaging across all issues, moving from extreme liberals to extreme conservatives is associated with a reduction in support for areas of expert consensus of a more modest 0.20 points $(\mathrm{p}<0.001)$. Taken together, there is strong support in our observational analyses for H1. Anti-intellectualism is a strong predictor of support for expert consensus above and beyond the effects of left-right ideology.

The argument in this paper is that anti-intellectualism motivates people to resist expert consensus where it exists. If this is true, what else might we observe in my data beyond the above correlation? We know from Zaller's (1992) work that elite discourse can have a polarizing effect on politically aware citizens. We might expect a similar result here. Politically interested citizens are more likely to pick up on signals of expert consensus in discourse, but only those who are trusting of experts and intellectuals will accept them when forming their opinions. I ran the same estimations as above, but interacting the anti-intellectualism index with political interest. The linear predictions from these models are shown below in Figure 3 and the estimates are found in Table A3 of the Appendix. Political interest polarizes citizens in their support of positions of expert consensus across levels of anti-intellectualism. Of course, politically interested citizens may not be reacting to

\footnotetext{
${ }^{9}$ It is possible that ideology exerts an influence on support for positions of expert consensus through anti-intellectualism. Engaging in observational mediation analysis is a daunting task (Green et al. 2010), but nonetheless this explanation is lacking. Adding anti-intellectualism into the observational models does not dampen the coefficients on ideology at all, on any issue. Details of these analyses are available upon request.

${ }^{10}$ The effect sizes are stronger in the MTurk sample compared to the GSS, but nonetheless they are comparable to results found in more representative samples. More details on this analysis can be found in Table S11 of the online supplementary material. Smaller effect sizes for the GSS are likely a function of limited variation in the independent variable and limited measurement validity.
} 
consensus cues per se. The experiment in the next section provides clearer causal evidence of this process. $^{11}$

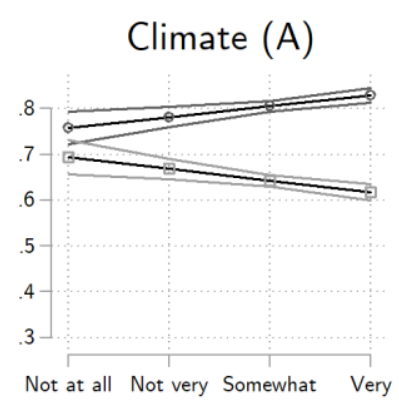

GMOs (C)

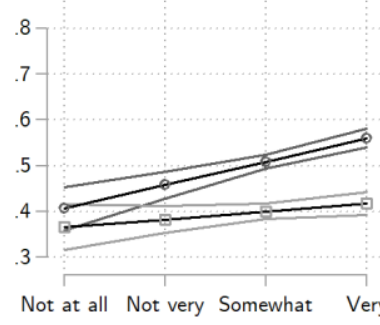

Nuclear (B)

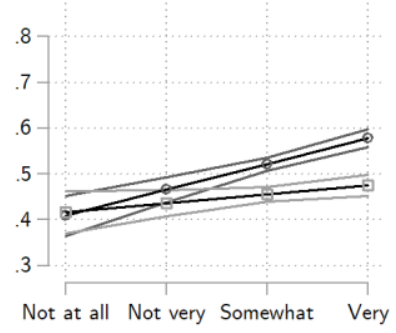

Fluoride (D)

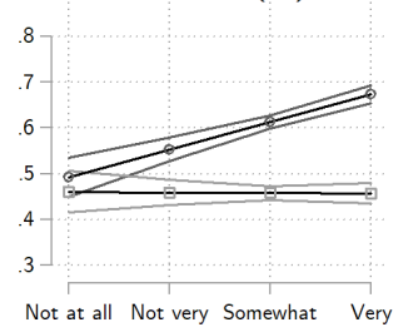

Combined (E)

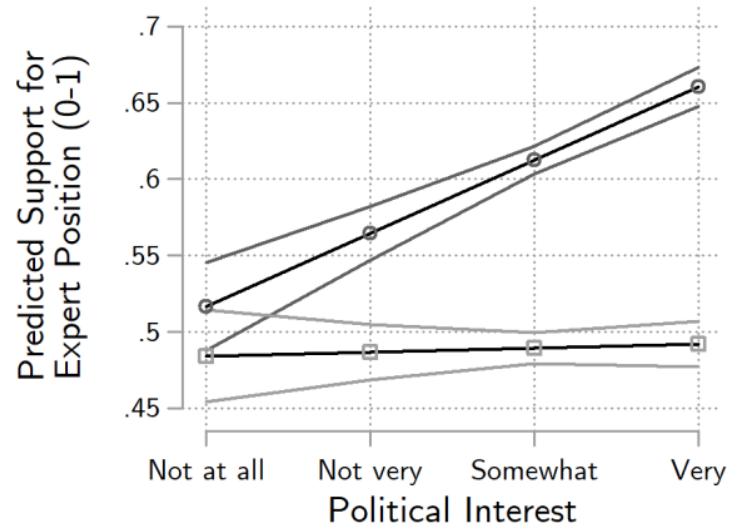

$\rightarrow-$ Low Al $\quad \longrightarrow-$ High Al

Figure 3. Predicted support for positions of expert consensus across levels of political interest for respondents with low (10pctl) and high levels of anti-intellectualism (90pctl). A) Climate change; B) Nuclear power; C) GMOs; D) Fluoride; E) Average across issues. Note: 90\% confidence intervals. $\mathrm{AI}=$ Anti-intellectualism.

\section{Experimental Design}

There appears to be an observational connection between anti-intellectualism and opposition to areas of expert consensus. An experiment can more convincingly establish a causal link between these factors. I embedded a 3X2 factorial design in the MTurk survey for the purpose of testing H2 and $\mathrm{H} 3$.

First, I randomly assigned subjects into three groups. The first treatment group was asked to read a mock news article from Reuters describing a political rally during which Senator Angus King (I-ME) used anti-elite rhetoric. The mock article was based coverage of a real rally held by Donald

\footnotetext{
${ }^{11}$ In contrast, there were only significant interactions of interest and ideology on climate change and fluoride. Estimates are provided in Table S4 of the online supplementary material. There is not a lot of variation in the measure of political interest, so analyses were run on all respondents $(\mathrm{N}=3614)$, controlling for treatment assignment, for more precise estimates.
} 
Trump as a Republican presidential candidate. The language was altered so that it could plausibly come from either a Democrat or a Republican politician. Importantly, none of the rhetoric taps into anti-intellectual themes or addresses the scientific issues used in this paper. The discussion is focused on corruption on Wall Street and in Washington. This allows me to test whether generalized antielite rhetoric activates anti-intellectualism. I used Senator King because his status as an independent senator from a small state would allow me to examine the effect of rhetoric independent of the partisanship of the source. The articles can be found in Figures S1-S4 in the online supplementary material.

The second group received an identical article with one exception - the source of the rhetoric was Donald Trump, for respondents who identify or lean towards the Republican Party, or Bernie Sanders, for everyone else. Sometimes the effectiveness of a message is dependent on speaker characteristics (Kuklinski and Hurley 1994). Bernie Sanders and Donald Trump have reputations as populist, anti-establishment politicians and are both very popular within their respective political constituencies. ${ }^{12}$ The third group - the control condition - instead read a short article related to a NASA discovery. ${ }^{13}$

Second, I randomly assigned subjects into two groups independent of the rhetoric treatment. One group received the battery of questions asking their opinions on climate change, nuclear power, GMOs, and water fluoridation with the following lead:

"Surveys indicate that most scientists and policy experts agree with the following statements. To what extent do you agree or disagree with these positions?"

The control group was simply asked to state their agreement or disagreement with each of those positions without such a lead. We should expect respondents in the treatment condition to be more supportive of the expert consensus position, but, in support of $\mathrm{H} 2$, that this effect should be

\footnotetext{
${ }^{12}$ There was little evidence that the source of the rhetoric made a difference in the results that follow as shown in Table S5 and Figure S5 of the online supplementary material, so these conditions will be collapsed for the following analysis.

${ }^{13}$ One might be concerned that this article might increase support for positions of expert consensus. It does not seem like this is the case. In an MTurk sample collected a year later, the share of subjects agreeing at some level with the climate consensus was an identical 80\%.
} 
weaker among those with higher levels of anti-intellectual sentiment. Further, we should expect this moderation effect to be stronger when respondents are exposed to anti-elite rhetoric $(\mathrm{H} 3)$. The combined experimental conditions are shown in Table 1.

Table 1. Experimental conditions

\begin{tabular}{|l|l|l|l|}
\hline & No consensus cue & Consensus cue & Total \\
\hline No rhetoric & $\mathrm{N}=619$ & $\mathrm{~N}=573$ & $\mathrm{~N}=1192$ \\
\hline Rhetoric - Non-partisan & $\mathrm{N}=590$ & $\mathrm{~N}=615$ & $\mathrm{~N}=1205$ \\
\hline Rhetoric - Partisan & $\mathrm{N}=580$ & $\mathrm{~N}=637$ & $\mathrm{~N}=1217$ \\
\hline Total & $\mathrm{N}=1789$ & $\mathrm{~N}=1825$ & $\mathrm{~N}=3614$ \\
\hline
\end{tabular}

The experimental protocol was as follows. Respondents consented to the survey and completed a number of pre-treatment questions gauging their political attitudes and demographics. They were then asked to read the mock news article, which they believed to be real news content, and answered a question battery gaging their support for positions of expert consensus. Finally, they were debriefed on the nature of the deception in the experiment, given the opportunity to withdraw their consent and provided a code to receive payment through Amazon. ${ }^{14} 15$

\section{Models}

$\mathrm{H} 2$ is tested using OLS regression with a model that includes an interaction of the scientific consensus cue and anti-intellectualism. However, we need to worry about confounders because moderating variables are observational (Kam and Trussler 2017). Thus, the treatment is also interacted with a series of controls $(\mathrm{X})$, including ideology and partisanship, generalized trust, and political interest. Ideology, partisanship, and generalized trust may affect how respondents process consensus cues from experts and are all correlated with anti-intellectualism as conceptualized and measured here. We also have some expectation that more politically sophisticated respondents will

\footnotetext{
${ }^{14} 83 \%$ passed a pair of attention checks embedded in the survey. 68 respondents withdrew their consent and were dropped from all analyses in the paper.

15 The expert trust battery was asked pre-consensus cue treatment, but post-rhetoric treatment. This design could potentially bias the results (Montgomery et al. 2018). However, there is no indication that my rhetoric manipulation influenced respondents' reported trust in experts. Diagnostic tests on this can be found in Table S6 of the online supplementary material.
} 
be less responsive to experimental manipulations, so it is controlled for as well. $\beta_{3}$ should be negative and significant to provide support for $\mathrm{H} 2$ :

support for expert position $=\alpha+\beta_{1}$ consensus cue $+\beta_{2}$ anti-intellectualism +

$\beta_{3}$ consensus cue $*$ anti-intellectualism $+\mathrm{X}+$ consensus cue $* \mathrm{X}+\varepsilon$

Finally, we expect anti-elite rhetoric treatment to prime anti-intellectuals to resist messages of expert consensus. This requires a three-way interaction between both treatments and antiintellectualism, as shown in equation 3:

support for expert position $=\alpha+\beta_{1}$ consensus cue $+\beta_{2}$ rhetoric $+\beta_{3}$ anti-intellectualism + $\beta_{4}$ consensus cue $*$ rhetoric $+\beta_{5}$ consensus cue $*$ anti-intellectualism + $\beta_{6}$ rhetoric $*$ anti-intellectualism $+\beta_{7}$ consensus cue $*$ rhetoric $*$ anti-intellectualism + $\mathrm{X}+$ consensus cue $* \mathrm{X}+\varepsilon$

\section{Experimental Results}

The treatment was effective for nuclear power ( $p \sim 0.05$ ), and for water fluoridation ( $p \sim 0.001$ ), but the effects are substantively small - a 0.02 point increase in support of the expert position for the former and a 0.03 point increase for the latter. This is to be expected as treatment effects for consensus cues are likely to be highly heterogeneous.

It appears that anti-intellectualism consistently moderates the effectiveness of the consensus cue treatment across in line with $\mathrm{H} 2$. The regression estimates are provided in Table A4 of the Appendix. ${ }^{16}$ The interaction is significant on three of the four issues below the 0.05 level. The marginal effects of these estimates are shown in Figure 4. Respondents that are the most trusting of experts are expected to increase their support for the climate consensus by a slight 0.02 points in response to the consensus cue, which is non-significant $(\mathrm{p} \sim 0.28)$. This decreases approximately 0.10 points for those with the highest levels of anti-intellectual sentiment such that the treatment will

\footnotetext{
${ }^{16}$ Table S7 of the online supplementary material presents the results of an OLS estimation without controls.
} 
reduce the support of these respondents for the expert position by a sizable 0.08 points $(\mathrm{p} \sim 0.02)$. That is, anti-intellectuals double down on their rejection of expert positions in response to a consensus cue. This finding is similar to the "backfire effect" sometimes (but not often) found in fact-checking experiments where directionally-motivated experimental subjects become more entrenched in their misperceptions in response to an intervention (Nyhan and Reifler 2010).

(A) Climate

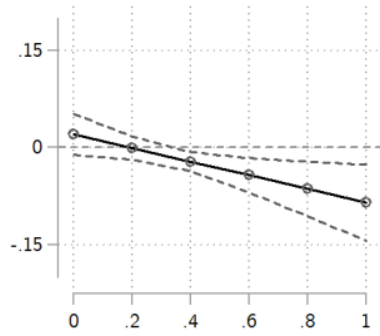

(C) GMOs

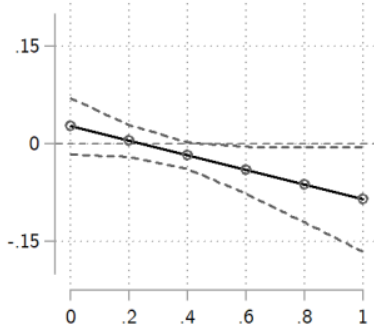

(B) Nuclear Power

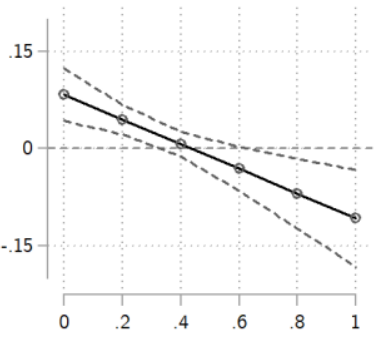

(D) Fluoride

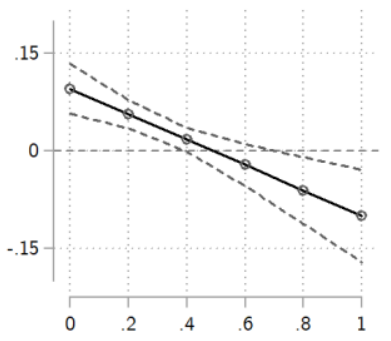

(E) Combined

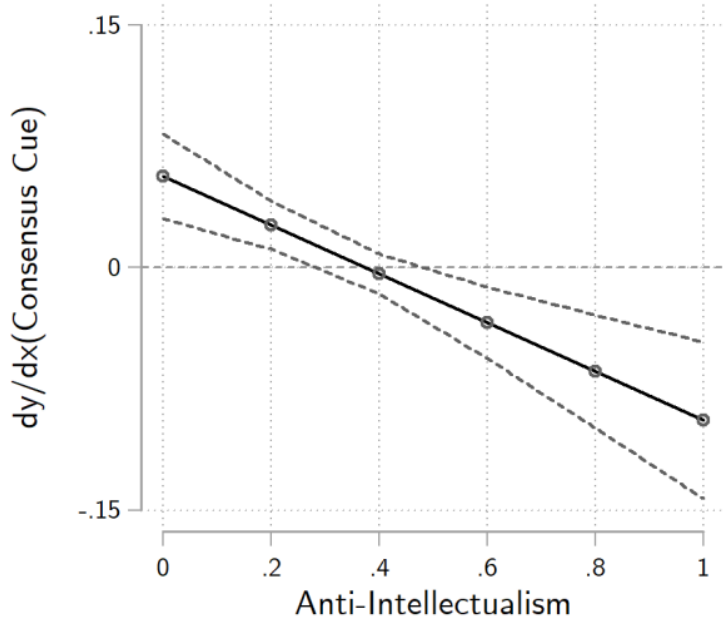

Figure 4. Marginal effects of expert consensus cue conditioned by anti-intellectualism. A) Climate change; B) Nuclear power; C) GMOs; D) Fluoride; E) Average across issues. Note: controls for ideology, partisanship, generalized trust, and political interest. $90 \%$ confidence intervals.

The strong moderating effect of anti-intellectualism is common for all of the issues used here. Respondents with the lowest levels of anti-intellectualism are expected to increase their support for the expert position on nuclear power by 0.08 points $(\mathrm{p} \sim 0.001)$. This effect decreases 0.19 points for those with the highest levels of anti-intellectualism such that they also reduce their agreement with the expert position by 0.11 points $(\mathrm{p} \sim 0.02)$. The interaction term is highly significant ( $\mathrm{p} \sim 0.004)$. The consensus cue also increases support for the expert position on fluoride by a substantial 0.10 points among those who are most trusting of experts $(\mathrm{p}<0.001)$, but with a similar backfire effect of 0.10 points for those with the highest levels of anti-intellectual sentiment ( $p \sim 0.02)$. Again, the interaction term is highly significant $(\mathrm{p} \sim 0.002)$. The interaction for GMOs is not quite significant after including controls but the results are pointing in the same direction $(\mathrm{p} \sim 0.11)$. 
Averaging across all issues, those most trusting of experts increase their support for positions of expert consensus by 0.06 points $(\mathrm{p}<0.001)$, while we expect a backfire effect of 0.09 points among those who have the highest levels of anti-intellectual sentiment $(\mathrm{p} \sim 0.001) .{ }^{17}$ The interaction term is highly significant $(\mathrm{p}<0.001)$. All told, there is strong support for H2. Anti-intellectualism appears to have a consistent moderating effect on the acceptance of consensus cues from experts. Echoing the observational findings, those trusting of experts accept consensus information, while those who do not fail to do so. These effects are modest in size, but are precisely estimated because of the large sample used here.

\section{Can anti-intellectualism be primed by populist rhetoric?}

We have strong theoretical grounds to expect an association between populism and antiintellectualism. I construct an index of populist sentiment in the GSS, based on institutional confidence questions, and in the MTurk survey with questions developed by Oliver and Rahn (2016).$^{18}$ I show that there is a strong association between these two variables in both the 2016 GSS and the MTurk sample. These results are provided in Figure S7 and Table S9 in the online supplementary material.

This finding is not particularly surprising given the anti-intellectual themes scholars have found in populist discourse. But, it also means that anti-elite rhetoric may prime those with strong anti-intellectual sentiment to resist signals of consensus from expert communities. It may do this even when the rhetoric is not about experts per se. The results for this test are presented below. The three-way interaction is difficult to interpret. So marginal effects plots are shown below in Figure 5. The estimates themselves are provided in Table A5 of the Appendix.

\footnotetext{
${ }^{17}$ There is little evidence that the observed backfire effect is the result of a linear specification. Table S8 and Figure S6 show the results of estimations with a quadratic anti-intellectualism term.

18 1) People like me don't have much say in what government does; 2) Politics usually boils down to a struggle between the people and the powerful; 3) The system is stacked against people like me; 4) It doesn't really matter who you vote for because the rich control both political parties; 5) People at the top usually get there from some unfair advantage. (7-point, strongly agree to strongly disagree).
} 
(A) Climate

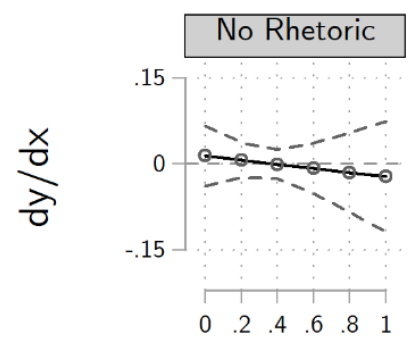

(C) GMOs
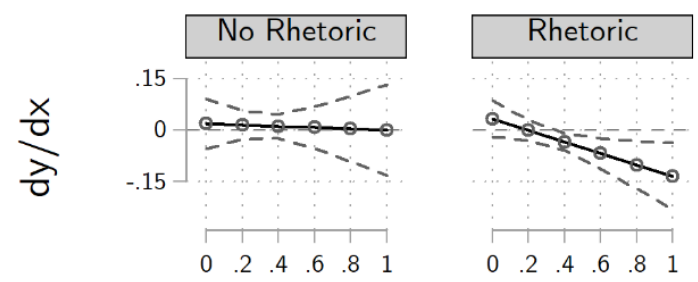

Anti-Intellectualism
(B) Nuclear
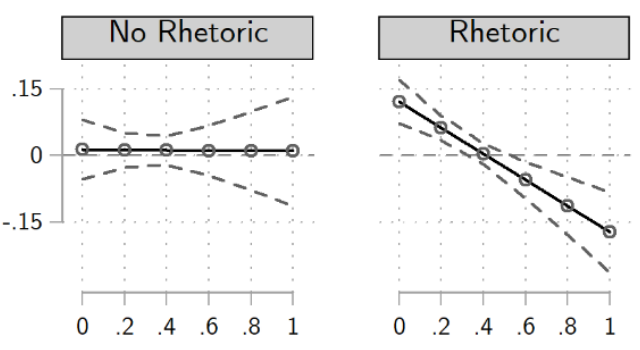

(D) Fluoride

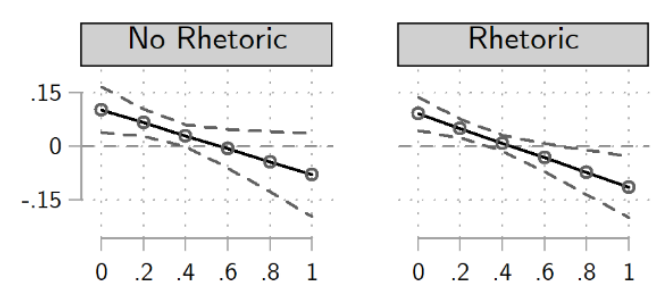

Anti-Intellectualism

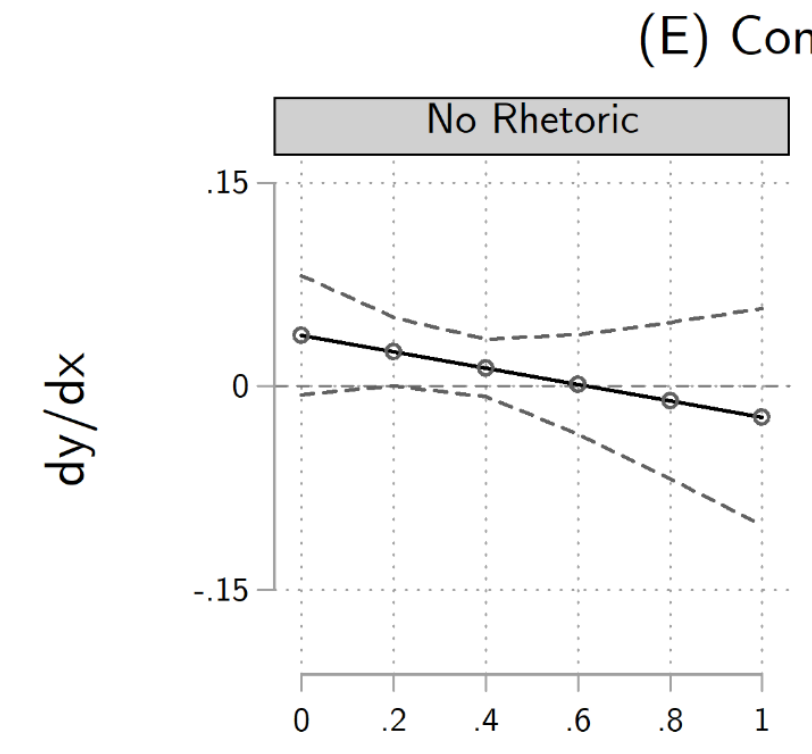

(E) Combined

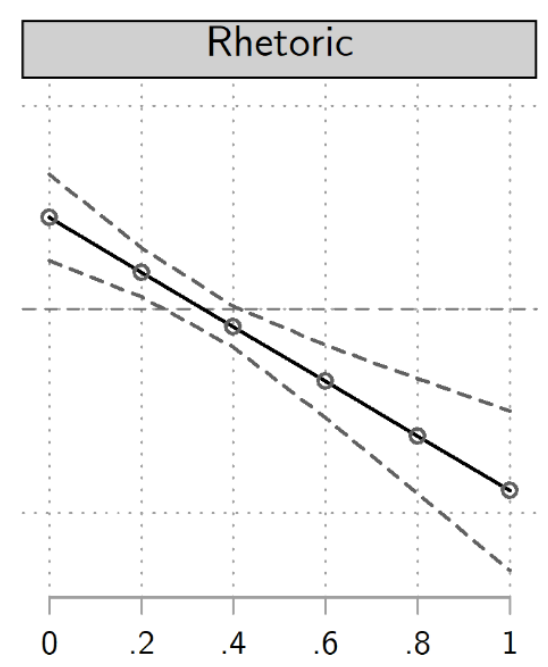

\section{Anti-Intellectualism}

Figure 5. Marginal effects of expert consensus cue conditioned by anti-intellectualism and anti-elite rhetoric. A) Climate change; B) Nuclear power; C) GMOs; D) Fluoride; E) Average across issues. Note: $90 \%$ confidence intervals.

The results provide some evidence that the anti-elite rhetoric primed those that mistrusted experts to resist the cue on three of four issues. Anti-intellectualism moderated the effectiveness of 
the consensus cue for climate change, nuclear power, and GMOs, but only when exposed to antielite rhetoric. ${ }^{19}$ These results provide compelling support for $\mathrm{H} 3$ and some troubling evidence that rising anti-elite rhetoric may undermine the persuasiveness of experts among the people that are in most need of persuading.

\section{Discussion}

Anti-intellectualism has been well-documented in American political life. But, we do not have a strong understanding of what this concept is, which citizens are more attracted to it, and the implications of this predisposition for political behaviour. This paper offers three primary contributions. First, this paper finds that anti-intellectualism - the generalized mistrust and suspicion of intellectuals and experts - has relevance for political behaviour in its own right, and not simply as a component of conservative ideology. Anti-intellectualism is a strong predictor of opposition to positions with widespread expert agreement, particularly for those with higher levels of political interest. This is true both on historically salient and highly polarized issues like climate change and nuclear power, as well as on issues of lesser salience and ideological charge, such as GMOs and water fluoridation (H1). Their consistency and strength as a predictor exceeds that of left-right ideology.

Second, this paper provides experimental evidence that anti-intellectualism limits one's propensity to accept cues signaling expert consensus (H2). Scholars seeking to understand what influences citizens' acceptance of expert messages should place more attention on antiintellectualism as a structuring predisposition. The finding that consensus cues have the potential to backfire on those who have the strongest levels of anti-intellectual sentiment is a troubling unintended consequence of these interventions. More work should be done to extend this finding to other science-based issues, and perhaps issues of consensus for communities of experts other than scientists and medical professionals.

\footnotetext{
${ }^{19}$ This activation effect appears to be stronger for those who are less politically interested - as we would expect - and that these respondents are generally more responsive to rhetoric from more clearly partisan sources. The marginal effects from this analysis can be found in Figure S8 of the online supplementary material. Results should be treated with caution. A larger sample size is needed for more precise, confident estimates.
} 
Third, this experiment shows that that populist rhetoric may play a role in priming antiintellectualism as a predisposition when citizens process information in their environment, even when that rhetoric doesn't directly pertain to experts (H3). Anti-intellectualism limited the acceptance of cues signaling expert consensus much more strongly when respondents were exposed to generalized anti-elite rhetoric. The implication is that rising populist rhetoric may make antiintellectualism a more salient determinant of support for expert positions in the future.

One important limitation of this study is its use of a non-representative, MTurk sample. However, there is some evidence that my sample compares favourably to others used in similar research. Motta (2018), for example, used an online panel, weighted to match American population characteristics, to identify an association between anti-intellectualism and skepticism of climate science. He found that crossing the whole range of his measure of anti-intellectualism, drawn from the work of Oliver and Rahn (2016), increases the likelihood of being a climate skeptic by 17-21\% depending on the survey wave. Using the same measure of anti-intellectualism, I found an increase of $16 \%$ in that same likelihood in my MTurk sample. More details on this analysis can be found in Table S11 of the online supplementary material.

The important role that anti-intellectualism plays structuring attitudes towards expert consensus poses a challenge to science communicators who have focused on communication strategies to overcome left-right ideological conflict. The prospect that consensus cues may backfire on a sizable, ideologically heterogeneous segment of citizens is troubling. It is unlikely that appeals to authority in the form of expert consensus cues will ever be persuasive to citizens that by definition are hostile to these information sources. Scholars should explore alternative messaging strategies with the aim of persuading these citizens of the merits of mainstream expert positions.

This problem is perhaps even more acute now amidst populist resurgence in the United States and Europe (Moffit 2016; Oliver and Rahn 2016). As populist rhetoric increasingly saturates political discourse, we can expect anti-intellectualism to be a stronger force in shaping citizen attitudes, including on areas of scientific and expert consensus. The politics of climate change may make it seem like anti-intellectualism is more prevalent in the United States, but misinformation on the safety of nuclear power and GMOs is strong in Europe as well. Future work should extend the study of anti-intellectualism beyond the United States.

But before that happens, we need stronger theorization of anti-intellectualism as a complex concept with a number of distinct sources, like ideology, populism, religious fundamentalism, and intuitionism. We could then map out how each of these sources of anti-intellectualism affect 
opposition to positions of expert consensus directly and indirectly through their influence on antiintellectualism. Much more work needs to be done in theorizing anti-intellectualism to situate this concept among related constructs and guide efforts at measurement so we can fully understand how it relates to mass behaviour.

\section{Appendix}

Table A1. Determinants of support for expert positions, GSS

\begin{tabular}{|c|c|c|c|}
\hline & Climate & Nuclear & GMO \\
\hline \multirow{2}{*}{ Confidence in Science (Reverse Coded) } & $-0.05^{*}$ & $-0.05^{*}$ & $-0.08^{* * *}$ \\
\hline & $(0.02)$ & $(0.02)$ & $(0.03)$ \\
\hline \multirow[t]{2}{*}{ Ideology } & $-0.07 *$ & $0.06+$ & 0.05 \\
\hline & $(0.03)$ & $(0.03)$ & $(0.04)$ \\
\hline \multirow[t]{2}{*}{ PID } & $-0.08^{* *}$ & $0.09 * *$ & 0.03 \\
\hline & $(0.02)$ & $(0.02)$ & $(0.03)$ \\
\hline \multirow[t]{2}{*}{ Male } & 0.01 & $0.09 * *$ & $0.11^{* *}$ \\
\hline & $(0.01)$ & $(0.01)$ & $(0.02)$ \\
\hline \multirow[t]{2}{*}{ Employed } & $-0.03 \dagger$ & 0.01 & 0.01 \\
\hline & $(0.01)$ & $(0.01)$ & $(0.02)$ \\
\hline \multirow[t]{2}{*}{ White } & 0.02 & $0.07 * *$ & 0.04 \\
\hline & $(0.02)$ & $(0.02)$ & $(0.02)$ \\
\hline \multirow[t]{2}{*}{ Age } & $-0.00^{*}$ & $0.00 * *$ & $0.00^{*}$ \\
\hline & $(0.00)$ & $(0.00)$ & $(0.00)$ \\
\hline \multirow[t]{2}{*}{ Income } & 0.00 & $0.01 *$ & 0.00 \\
\hline & $(0.00)$ & $(0.00)$ & $(0.00)$ \\
\hline \multirow[t]{2}{*}{ Education } & -0.00 & $0.02 * *$ & 0.01 \\
\hline & $(0.01)$ & $(0.01)$ & $(0.01)$ \\
\hline \multirow[t]{2}{*}{ Church Attendance } & -0.00 & -0.00 & 0.00 \\
\hline & $(0.00)$ & $(0.00)$ & $(0.00)$ \\
\hline \multirow[t]{2}{*}{ Trust } & 0.00 & $-0.03^{* *}$ & -0.01 \\
\hline & $(0.01)$ & $(0.01)$ & $(0.01)$ \\
\hline Constant & $0.75^{* *}$ & -0.04 & $0.22^{* *}$ \\
\hline $\mathrm{R}^{2}$ & 0.03 & 0.17 & 0.10 \\
\hline $\mathrm{N}$ & 1868 & 2024 & 1047 \\
\hline
\end{tabular}

Note: Sampling weight WTSSALL applied. Standard errors in parentheses, $\uparrow \mathrm{p}<0.1,{ }^{*} \mathrm{p}<0.05$, $* * \mathrm{p}<0.01$ 
Table A2. Determinants of support for expert positions, MTurk

\begin{tabular}{|c|c|c|c|c|c|}
\hline & $\begin{array}{c}\text { Climate } \\
1\end{array}$ & $\begin{array}{c}\text { Nuclear } \\
2\end{array}$ & $\begin{array}{c}\text { GMO } \\
3 \\
\end{array}$ & $\begin{array}{c}\text { Fluoride } \\
4\end{array}$ & $\begin{array}{c}\text { Combined } \\
5 \\
\end{array}$ \\
\hline Anti-intellectualism & $\begin{array}{c}-0.39 * * \\
(0.06)\end{array}$ & $\begin{array}{c}-0.23 * * \\
(0.08)\end{array}$ & $\begin{array}{c}-0.29 * * \\
(0.08)\end{array}$ & $\begin{array}{c}-0.28^{* *} \\
(0.08)\end{array}$ & $\begin{array}{c}-0.30 * * \\
(0.05)\end{array}$ \\
\hline Ideology & $\begin{array}{c}-0.43^{* *} \\
(0.06)\end{array}$ & $\begin{array}{l}-0.03 \\
(0.08)\end{array}$ & $\begin{array}{l}-0.17^{*} \\
(0.08)\end{array}$ & $\begin{array}{l}-0.18^{*} \\
(0.08)\end{array}$ & $\begin{array}{c}-0.20^{* *} \\
(0.05)\end{array}$ \\
\hline PID & $\begin{array}{l}-0.02 \\
(0.05)\end{array}$ & $\begin{array}{c}0.06 \\
(0.06)\end{array}$ & $\begin{array}{c}0.10 \\
(0.07)\end{array}$ & $\begin{array}{c}0.05 \\
(0.06)\end{array}$ & $\begin{array}{c}0.05 \\
(0.04)\end{array}$ \\
\hline Male & $\begin{array}{c}0.01 \\
(0.02)\end{array}$ & $\begin{array}{c}0.12^{* *} \\
(0.03)\end{array}$ & $\begin{array}{c}0.04 \\
(0.03)\end{array}$ & $\begin{array}{l}0.05^{*} \\
(0.03)\end{array}$ & $\begin{array}{l}0.06 * * \\
(0.02)\end{array}$ \\
\hline Employed & $\begin{array}{c}0.02 \\
(0.02)\end{array}$ & $\begin{array}{l}-0.01 \\
(0.03)\end{array}$ & $\begin{array}{c}0.00 \\
(0.03)\end{array}$ & $\begin{array}{c}0.01 \\
(0.03)\end{array}$ & $\begin{array}{c}0.01 \\
(0.02)\end{array}$ \\
\hline White & $\begin{array}{c}0.02 \\
(0.02)\end{array}$ & $\begin{array}{l}0.06^{*} \\
(0.03)\end{array}$ & $\begin{array}{c}0.02 \\
(0.03)\end{array}$ & $\begin{array}{c}0.02 \\
(0.03)\end{array}$ & $\begin{array}{c}0.03 \\
(0.02)\end{array}$ \\
\hline Age & $\begin{array}{c}0.00 \\
(0.00)\end{array}$ & $\begin{array}{r}-0.00 \dagger \\
(0.00)\end{array}$ & $\begin{array}{c}-0.01 * * \\
(0.00)\end{array}$ & $\begin{array}{l}-0.00 \\
(0.00)\end{array}$ & $\begin{array}{c}-0.00^{* *} \\
(0.00)\end{array}$ \\
\hline Income & $\begin{array}{l}-0.00 \\
(0.01)\end{array}$ & $\begin{array}{l}0.01 \dagger \\
(0.01)\end{array}$ & $\begin{array}{c}0.00 \\
(0.01)\end{array}$ & $\begin{array}{c}0.01 \\
(0.01)\end{array}$ & $\begin{array}{c}0.00 \\
(0.01)\end{array}$ \\
\hline Education & $\begin{array}{l}-0.00 \\
(0.01)\end{array}$ & $\begin{array}{c}0.05^{* *} \\
(0.02)\end{array}$ & $\begin{array}{c}0.06^{* *} \\
(0.02)\end{array}$ & $\begin{array}{l}0.04 * * \\
(0.01)\end{array}$ & $\begin{array}{l}0.04 * * \\
(0.01)\end{array}$ \\
\hline Church Attendance & $\begin{array}{c}0.00 \\
(0.00)\end{array}$ & $\begin{array}{l}-0.00 \\
(0.00)\end{array}$ & $\begin{array}{l}-0.00 \\
(0.01)\end{array}$ & $\begin{array}{l}-0.00 \\
(0.00)\end{array}$ & $\begin{array}{l}-0.00 \\
(0.00)\end{array}$ \\
\hline Trust & $\begin{array}{l}-0.01 \\
(0.01)\end{array}$ & $\begin{array}{l}0.04 * \\
(0.02)\end{array}$ & $\begin{array}{c}0.06^{* *} \\
(0.02)\end{array}$ & $\begin{array}{l}0.03 * \\
(0.02)\end{array}$ & $\begin{array}{l}0.03 * * \\
(0.01)\end{array}$ \\
\hline Political Interest & $\begin{array}{c}0.02 \\
(0.01)\end{array}$ & $\begin{array}{l}0.03 \dagger \\
(0.02)\end{array}$ & $\begin{array}{c}0.03 \\
(0.02)\end{array}$ & $\begin{array}{l}0.04 * \\
(0.02)\end{array}$ & $\begin{array}{c}0.03^{* *} \\
(0.01)\end{array}$ \\
\hline Constant & $1.03^{* *}$ & $0.23 * *$ & $0.44 * *$ & $0.39 * *$ & $0.52^{* *}$ \\
\hline $\mathrm{R}^{2}$ & 0.34 & 0.14 & 0.15 & 0.13 & 0.26 \\
\hline $\mathrm{N}$ & 552 & 552 & 552 & 552 & 552 \\
\hline
\end{tabular}

Note: standard errors in parentheses, $\mathrm{tp}_{\mathrm{p}}<0.1,{ }^{*} \mathrm{p}<0.05,{ }^{*} \mathrm{p}<0.01$ 
Table A3. Political interest, anti-intellectualism interaction, MTurk, all respondents

\begin{tabular}{lccccc}
\hline & Climate & Nuclear & GMOs & Fluoride & Combined \\
\hline Anti-intellectualism & $-0.15 \dagger$ & 0.02 & -0.09 & -0.07 & -0.08 \\
& $(0.08)$ & $(0.10)$ & $(0.10)$ & $(0.09)$ & $(0.06)$ \\
Political Interest & $0.04^{* *}$ & $0.07^{* *}$ & $0.06^{* *}$ & $0.08^{* *}$ & $0.06^{* *}$ \\
& $(0.01)$ & $(0.02)$ & $(0.02)$ & $(0.02)$ & $(0.01)$ \\
Interest* Anti-intellectualism & $-0.11^{* *}$ & $-0.09^{*}$ & $-0.08 \dagger$ & $-0.14^{* *}$ & $-0.10^{* *}$ \\
& $(0.03)$ & $(0.04)$ & $(0.04)$ & $(0.04)$ & $(0.03)$ \\
Constant & $1.03 \dagger$ & $0.32^{* *}$ & $0.49^{* *}$ & $0.43^{* *}$ & 0.57 \\
\hline Controls & Yes & Yes & Yes & Yes & Yes \\
$\mathrm{R}^{2}$ & 0.37 & 0.09 & 0.13 & 0.12 & 0.23 \\
$\mathrm{~N}$ & 3187 & 3187 & 3187 & 3187 & 3187 \\
\hline $\mathrm{N}$ & &
\end{tabular}

Note: controls for ideology, partisanship, gender, employment, race, age, income, religiosity, and generalized trust; standard errors in parentheses, $\mathrm{tp}_{\mathrm{p}}<0.1,{ }^{*} \mathrm{p}<0.05,{ }^{*} \mathrm{p}<0.01$ 
Table A4. Consensus cue treatment moderated by anti-intellectualism

\begin{tabular}{|c|c|c|c|c|c|}
\hline & $\begin{array}{c}\text { Climate } \\
1\end{array}$ & $\begin{array}{c}\text { Nuclear } \\
2\end{array}$ & $\begin{array}{c}\text { GMO } \\
3\end{array}$ & $\begin{array}{c}\text { Fluoride } \\
4\end{array}$ & $\begin{array}{c}\text { Combined } \\
5\end{array}$ \\
\hline Anti-intellectualism & $\begin{array}{c}-0.36^{* *} \\
(0.04)\end{array}$ & $\begin{array}{l}-0.09 \dagger \\
(0.05)\end{array}$ & $\begin{array}{c}-0.23^{* *} \\
(0.05)\end{array}$ & $\begin{array}{c}-0.29 * * \\
(0.04)\end{array}$ & $\begin{array}{c}-0.24^{* *} \\
(0.03)\end{array}$ \\
\hline Cue ${ }^{*}$ Anti-intellectualism & $\begin{array}{l}-0.10 \\
(0.05)\end{array}$ & $\begin{array}{c}-0.19 * * \\
(0.07)\end{array}$ & $\begin{array}{l}-0.11 \\
(0.07)\end{array}$ & $\begin{array}{c}-0.20 * * \\
(0.06)\end{array}$ & $\begin{array}{c}-0.15^{* *} \\
(0.04)\end{array}$ \\
\hline Ideology & $\begin{array}{c}-0.32^{* *} \\
(0.03)\end{array}$ & $\begin{array}{l}-0.00 \\
(0.04)\end{array}$ & $\begin{array}{c}-0.15^{* *} \\
(0.05)\end{array}$ & $\begin{array}{c}-0.12^{* *} \\
(0.04)\end{array}$ & $\begin{array}{c}-0.15^{* *} \\
(0.03)\end{array}$ \\
\hline Cue * Ideology & $\begin{array}{l}-0.03 \\
(0.05)\end{array}$ & $\begin{array}{c}0.01 \\
(0.06)\end{array}$ & $\begin{array}{l}-0.03 \\
(0.06)\end{array}$ & $\begin{array}{l}0.11^{*} \\
(0.06)\end{array}$ & $\begin{array}{c}0.02 \\
(0.04)\end{array}$ \\
\hline PID & $\begin{array}{c}-0.13 * * \\
(0.03)\end{array}$ & $\begin{array}{l}0.06 \dagger \\
(0.04)\end{array}$ & $\begin{array}{c}0.05 \\
(0.04)\end{array}$ & $\begin{array}{c}0.02 \\
(0.03)\end{array}$ & $\begin{array}{c}0.00 \\
(0.02)\end{array}$ \\
\hline Cue * PID & $\begin{array}{l}-0.04 \\
(0.04)\end{array}$ & $\begin{array}{l}-0.02 \\
(0.05)\end{array}$ & $\begin{array}{l}-0.02 \\
(0.05)\end{array}$ & $\begin{array}{l}-0.07 \\
(0.05)\end{array}$ & $\begin{array}{l}-0.04 \\
(0.03)\end{array}$ \\
\hline Trust & $\begin{array}{c}0.01 \\
(0.01)\end{array}$ & $\begin{array}{c}0.05^{* *} \\
(0.01)\end{array}$ & $\begin{array}{c}0.05^{* *} \\
(0.01)\end{array}$ & $\begin{array}{c}0.04^{* *} \\
(0.01)\end{array}$ & $\begin{array}{c}0.04 * * \\
(0.01)\end{array}$ \\
\hline Cue $*$ Trust & $\begin{array}{l}-0.02 \dagger \\
(0.01)\end{array}$ & $\begin{array}{l}-0.03^{*} \\
(0.01)\end{array}$ & $\begin{array}{l}-0.02 \\
(0.01)\end{array}$ & $\begin{array}{l}-0.01 \\
(0.01)\end{array}$ & $\begin{array}{l}-0.02 * \\
(0.01)\end{array}$ \\
\hline Political Interest & $\begin{array}{c}0.01 \\
(0.01)\end{array}$ & $\begin{array}{l}0.05^{* *} \\
(0.01)\end{array}$ & $\begin{array}{c}0.05^{* *} \\
(0.01)\end{array}$ & $\begin{array}{c}0.05^{* *} \\
(0.01)\end{array}$ & $\begin{array}{c}0.04 * * \\
(0.01)\end{array}$ \\
\hline Cue $*$ Political Interest & $\begin{array}{l}-0.03^{*} \\
(0.01)\end{array}$ & $\begin{array}{l}-0.00 \\
(0.02)\end{array}$ & $\begin{array}{l}-0.03 \\
(0.02)\end{array}$ & $\begin{array}{l}-0.03 \dagger \\
(0.01)\end{array}$ & $\begin{array}{l}-0.02^{*} \\
(0.01)\end{array}$ \\
\hline Consensus Cue & $\begin{array}{l}0.13 * * \\
(0.04)\end{array}$ & $\begin{array}{l}0.12 * * \\
(0.05)\end{array}$ & $\begin{array}{l}0.12^{*} \\
(0.05)\end{array}$ & $\begin{array}{l}0.15^{* *} \\
(0.04)\end{array}$ & $\begin{array}{l}0.13 * * \\
(0.03)\end{array}$ \\
\hline Constant & $1.02 * *$ & $0.34 * *$ & $0.44 * *$ & $0.53 * *$ & $0.59 * *$ \\
\hline $\begin{array}{l}\mathrm{R}^{2} \\
\mathrm{~N}\end{array}$ & $\begin{array}{l}0.37 \\
3213\end{array}$ & $\begin{array}{l}0.04 \\
3213\end{array}$ & $\begin{array}{l}0.07 \\
3213\end{array}$ & $\begin{array}{l}0.10 \\
3213\end{array}$ & $\begin{array}{l}0.19 \\
3213\end{array}$ \\
\hline
\end{tabular}

Note: Standard errors in parentheses, $\dagger \mathrm{p}<0.1,{ }^{* *} \mathrm{p}<0.05,{ }^{* * *} \mathrm{p}<0.01$ 
Table A5. Consensus cue treatment moderated by anti-intellectualism and rhetoric

\begin{tabular}{|c|c|c|c|c|c|}
\hline & $\begin{array}{c}\text { Climate } \\
1\end{array}$ & $\begin{array}{c}\text { Nuclear } \\
2\end{array}$ & $\begin{array}{c}\text { GMO } \\
3\end{array}$ & $\begin{array}{c}\text { Fluoride } \\
4\end{array}$ & $\begin{array}{c}\text { Combined } \\
5\end{array}$ \\
\hline \multirow[t]{2}{*}{ Consensus Cue } & $0.13^{* *}$ & 0.05 & $0.11 \dagger$ & $0.16^{* *}$ & $0.11^{* *}$ \\
\hline & $(0.04)$ & $(0.06)$ & $(0.06)$ & $(0.05)$ & $(0.04)$ \\
\hline \multirow[t]{2}{*}{ Anti-intellectualism } & $-0.36 * *$ & $-0.27 * *$ & $-0.36 * *$ & $-0.32 * *$ & $-0.33 * *$ \\
\hline & $(0.06)$ & $(0.08)$ & $(0.08)$ & $(0.07)$ & $(0.05)$ \\
\hline \multirow[t]{2}{*}{ Cue * Anti-intellectualism } & -0.04 & -0.00 & -0.02 & $-0.18 \dagger$ & -0.06 \\
\hline & $(0.09)$ & $(0.11)$ & $(0.12)$ & $(0.10)$ & $(0.07)$ \\
\hline \multirow[t]{2}{*}{ Rhetoric } & -0.00 & $-0.11 * *$ & -0.04 & 0.00 & $-0.04 \dagger$ \\
\hline & $(0.03)$ & $(0.03)$ & $(0.04)$ & $(0.03)$ & $(0.02)$ \\
\hline \multirow{2}{*}{ Cue * Rhetoric } & 0.01 & $0.11 *$ & 0.01 & -0.01 & 0.03 \\
\hline & $(0.04)$ & $(0.05)$ & $(0.05)$ & $(0.05)$ & $(0.03)$ \\
\hline \multirow[t]{2}{*}{ Rhetoric * Anti-intellectualism } & 0.00 & $0.28^{* *}$ & $0.20^{*}$ & 0.04 & $0.13^{*}$ \\
\hline & $(0.07)$ & $(0.09)$ & $(0.10)$ & $(0.09)$ & $(0.06)$ \\
\hline \multirow[t]{2}{*}{ Cue $*$ Rhetoric $*$ Anti-intellectualism } & -0.10 & $-0.29 *$ & -0.15 & -0.02 & $-0.14 \dagger$ \\
\hline & $(0.10)$ & $(0.13)$ & $(0.14)$ & $(0.13)$ & $(0.09)$ \\
\hline Constant & $1.02^{* *}$ & $0.41 * *$ & $0.47 * *$ & $0.53^{* *}$ & $0.61 * *$ \\
\hline $\mathrm{R}^{2}$ & 0.37 & 0.04 & 0.08 & 0.10 & 0.19 \\
\hline $\mathrm{N}$ & 3213 & 3213 & 3213 & 3213 & 3213 \\
\hline
\end{tabular}

Note: Controls for ideology, partisanship, generalized trust, and political interest interacted with the treatment. Standard errors in parentheses, $\uparrow \mathrm{p}<0.1,{ }^{*} \mathrm{p}<0.05,{ }^{*} \mathrm{p}<0.01$ 


\section{References}

Barker, David C. 2005. "Values, Frames, and Persuasion in Presidential Nomination Campaigns." Political Behavior 27:375-94.

Berinsky, Adam J. 2017. "Rumors and Health Care Reform: Experiments in Political Misinformation." British Journal of Political Science 47:241-62.

Brewer, Mark D. 2016. "Populism in American Politics." The Forum 14:249-64.

Chaiken, Shelly. 1980. "Heuristic Versus Systematic Information Processing and the Use of Source Versus Message Cues in Persuasion.” Journal of Personality and Social Psychology 37:1387-97.

Clifford, Scott, Jennifer Jerit, Carlisle Rainey, and Matt Motyl. 2015. "Moral Concerns and Policy Attitudes: Investigating the Influence of Elite Rhetoric.” Political Communication 32:229-48.

Ditto, Peter H., and David F. Lopez. 1992. "Motivated Skepticism: Use of Differential Decision Criteria for Preferred and Nonpreferred Conclusions." Journal of Personality and Social Psychology 63:568-84.

Druckman, James N., and Justin W. Holmes. 2004. "Does Presidential Rhetoric Matter? Priming and Presidential Approval.” Presidential Studies Quarterly 34:755-78.

Feinberg, Matthew, and Robb Willer. 2013. “The Moral Roots of Environmental Attitudes.” Psychological Science 24:56-62.

Green, Donald P., Shang E. Ha, and John G. Bullock. 2010. 'Enough Already about 'Black Box' Experiments: Studying Mediation Is More Difficult than Most Scholars Suppose.” The ANNALS of the American Academy of Political and Social Science 628:200-8.

Haider-Markel, Donald P., and Mark R. Joslyn. 2001. “Gun Policy, Opinion, Tragedy, and Blame Attribution: The Conditional Influence of Issue Frames.” Journal of Politics 63:520-43.

Haidt, Jonathan. 2001. “The Emotional Dog and its Rational Tail: A Social Intuitionist Approach to Moral Judgment.” Psychological Review 108:814-34.

Harris, Lee. 2010. The Next American Civil War: The Populist Revolt Against the Liberal Elite. New York: Palgrave-MacMillan.

Hofstadter, Richard. 1962. Anti-intellectualism in American life. New York: Random House.

Iyengar, Shanto, and Donald R. Kinder. 1987. News That Matters: Television and American Opinion. Chicago: University of Chicago Press. 
Kahan, Dan M., Hank Jenkins-Smith, and Donald Braman. 2011. "Cultural Cognition of Scientific Consensus." Journal of Risk Research 14:147-74.

Kam, Cindy D., and Marc J. Trussler. 2017. “At the Nexus of Observational and Experimental Research: Theory, Specification, and Analysis of Experiments with Heterogeneous Treatment Effects." Political Behavior 39:789-815.

Kazin, Michael. 1995. The Populist Persuasion. New York: Basic Books.

Kidwell, Blair, Adam Farmer, and David M. Hardesty. 2013. "Getting Liberals and Conservatives to Go Green: Political Ideology and Congruent Appeals.” Journal of Consumer Research 40:350-67.

Kuklinski, James H., and Norman L. Hurley. 1994. "On Hearing and Interpreting Political Messages: A Cautionary Tale of Citizen Cue-Taking." Journal of Politics 56:729-51.

Kunda, Ziva. 1990. “The Case for Motivated Reasoning.” Psychological Bulletin 108:480-98.

Lewandowsky, Stephan, and Klaus Oberauer. 2016. "Motivated Rejection of Science.” Current Directions in Psychological Science 25:217-22.

Lim, Elvin T. 2008. The Anti-intellectual Presidency: The Decline of Presidential Rhetoric from George Washington to George W. Bush. New York: Oxford University Press.

Lupia, Arthur, and Matthew D. McCubbins. 1998. The Democratic Dilemma: Can Citizens Learn What They Need to Know? Cambridge University Press.

Mendelberg, Tali. 2001. The Race Card: Campaign Strategy, Implicit Messages, and the Norm of Equality. Princeton, NJ: Princeton University Press.

Moffitt, Benjamin. 2016. The Global Rise of Populism: Performance, Political Style, and Representation. Stanford: Stanford University Press.

Montgomery, Jacob M., Brendan Nyhan, and Michelle Torres. 2018. "How Conditioning on Posttreatment Variables Can Ruin Your Experiment and What to Do about It.” American Journal of Political Science 62:760-75.

Motta, Matthew. 2018. "The Dynamics and Political Implications of Anti-Intellectualism in the United States." American Politics Research 46:465-98.

Mudde, Cas. 2004. "The Populist Zeitgeist.” Government and Opposition 39:541-63.

Nyhan, Brendan, and Jason Reifler. 2010. "When Corrections Fail: The Persistence of Political Misperceptions." Political Behavior 32:303-30. 
Nyhan, Brendan, and Jason Reifler, 2015. "Displacing Misinformation about Events: An Experimental Test of Causal Corrections." Journal of Experimental Political Science 2:81-93.

Oliver, J. Eric, and Thomas Wood. 2018. Enchanted America: How Intuition and Reason Divide our Politics. Chicago: University of Chicago Press.

Oliver, J. Eric, and Wendy M. Rahn. 2016. "Rise of the Trumpenvolk: Populism in the 2016 Election." The ANNALS of the American Academy of Political and Social Science 667:189-206.

Pew Research Center. 2015. "Public and Scientists' Views on Science and Society." http://assets.pewresearch.org/wpcontent/uploads/sites/14/2015/01/PI ScienceandSociety_Report 012915.pdf

Petty, Richard E., and John T. Cacioppo. 1979. "Issue Involvement Can Increase or Decrease Persuasion by Enhancing Message-Relevant Cognitive Responses." Journal of Personality and Social Psychology 37:1915-26.

Rigney, Daniel. 1991. “Three Kinds of Anti-intellectualism: Rethinking Hofstadter.” Sociological Inquiry 6:434-51.

Rooduijn, Matthijs. 2014. "The Nucleus of Populism: In Search of the Lowest Common Denominator." Government and Opposition 49:573-99.

Shen, Fuyuan, and Heidi Hatfield Edwards. 2005. "Economic Individualism, Humanitarianism, and Welfare Reform: A Value-Based Account of Framing Effects." Journal of Communication 55:795-809.

Shogan, Colleen J. 2007. "Anti-intellectualism in the Modern Presidency: A Republican Populism." Perspectives on Politics 5:295-303.

Skocpol, Theda, and Vanessa Williamson. 2013. The Tea Party and the Remaking of American Conservatism. New York: Oxford University Press.

Taggart, Paul. 2000. Populism. Buckingham: Open University Press.

van der Linden, Sander L, Anthony A. Leiserowitz, Geoffrey D. Feinberg, and Edward W. Maibach. 2015. "The Scientific Consensus on Climate Change as a Gateway Belief: Experimental Evidence." PloS One 10:e118489-e0118489.

van der Linden, Sander, Anthony Leiserowitz, and Edward Maibach. 2019. "The Gateway Belief Model: A Large-Scale Replication.” Journal of Environmental Psychology 62:49-58. 
Wood, Thomas, and Ethan Porter. 2019. “The Elusive Backfire Effect: Mass Attitudes' Steadfast Factual Adherence.” Political Behavior 41:135-63.

Winterich, Karen Page, Yinlong Zhang, and Vikas Mittal. 2012. "How Political Identity and Charity Positioning Increase Donations: Insights from Moral Foundations Theory." International Journal of Research in Marketing 29:346-54.

Zaller, John. 1992. The Nature and Origins of Mass Opinion. Cambridge: Cambridge University Press. 